FAKULTAS ILMU KESEHATAN UNIVERSITAS PEKALONGAN

http://jurnal.unikal.ac.id/index.php/medika ISSN : 2086-843X

\title{
Karakteristik Pasien Demam Tifoid Rawat Inap Kabupaten Pekalongan Tahun 2018
}

\author{
Ainun Muthoharoh ${ }^{1}$, Siti Rozanah ${ }^{2}$, Isyti'aroh ${ }^{3}$, Yulian Wahyu Permadi ${ }^{4}$ \\ ${ }^{1,2,4}$ Program Studi Sarjana Farmasi Fakultas Ilmu Kesehatan Universitas Muhammadiyah Pekajangan \\ Pekalongan, \\ ${ }^{3}$ Program Studi Diploma Keperawatan Fakultas Ilmu Kesehatan Universitas Muhammadiyah Pekajangan \\ Pekalongan, Coresponding author : ainun.muthoharoh@umpp.ac.id
}

\section{ARTICLE INFO :}

Accepted

Approve

Publish

\begin{abstract}
Typhoid fever, known as typhus, is an acute disease caused by Salmonella typhi bacterial infection. Typhoid fever is influenced by individual hygiene levels, environmental sanitation, and can be transmitted through the consumption of food or drinks that are contaminated with the feces or urine of an infected person. The purpose of this study was to determine the characteristics of typhoid fever sufferers undergoing hospitalization.This research is observational (non-experimental). This study uses a retrospective cohort approach with research data in the form of medical records of typhoid fever patients in 2018 at Kraton District Hospital in Pekalongan Regency. The population of typhoid fever was 343 patients and the sample was taken by simple random sampling of 185. Data analysis used frequency distribution.As many as 185 patients found the highest typhoid fever sufferers in women were 119 with a percentage (64.3\%) while men were 66 patients with a percentage (35.7\%). Based on the highest age at the age of 17-25 years with a percentage (23.2\%), for patients with a diagnosis of typhoid fever as many as 144 patients $(77.8 \%)$ and typhoid fever with comorbidities as many as 41 patients (22.2).The need for special attention to patients with female sex, so that they can take precautions that can cause typhoid fever.
\end{abstract}

Keywords : typhoid fever, characteristics, hospitalization

\begin{abstract}
ABSTRAK
Demam tifoid dikenal sebagai tifus merupakan penyakit akut yang disebabkan oleh infeksi bakteri Salmonella typhi.Penyakit demam tifoid dipengaruhi oleh tingkat higienis individu, sanitasi lingkungan, dan dapat menular melalui konsumsi makanan atau minuman yang terkontaminasi oleh feses atau urin orang yang terinfeksi. Tujuan dari penelitian untuk mengetahui karakteristik penderita demam tifoid yang menjalani rawat inap. Penelitian ini bersifat observasional (non eksperimental). Penelitian ini menggunakan pendekatan kohort retrospektif dengan data penelitian berupa rekam medis pasien demam tifoid pada tahun 2018 di RSUD Kraton Kabupaten Pekalongan. Populasi demam tifoid sebanyak 343 pasien dan sampel diambil secara simple random sampling sebanyak 185. Analisis data menggunakan ditribusi frekuensi. Sebanyak 185 pasien didapatkan penderita demam tifoid tertinggi pada perempuan sebanyak 119 dengan persentase $(64,3 \%)$ sedangkan laki-laki sebanyak 66 pasien dengan persentase $(35,7 \%)$. Berdasarkan usia tertinggi pada usia $17-25$ tahun dengan persentase $(23,2 \%)$,
\end{abstract}


untuk pasien dengan diagnosa demam tifoid saja sebanyak 144 pasien $(77,8 \%)$ dan demam tifoid dengan penyakit penyerta sebanyak 41 pasien $(22,2)$. Perlunya perhatian khusus kepada penderita dengan jenis kelamin perempuan, agar dapat melakukan pencegahan yang dapat menyebabkan timbulnya demam tifoid.

Kata kunci: demam tifoid, karakteristik, rawat inap

PENDAHULUAN

Demam tifoid di kenal juga dengan tifus merupakan penyakit akut yang disebabkan oleh infeksi bakteri Salmonella typhi (Alba, 2016). Penularan demam tifoid dapat melalui fecal dan oral yang masuk ke dalam tubuh manusia melalui makanan dan minuman yang terkontaminasi (Mogasale, dkk., 2016). Berdasarkan Profil Kesehatan Indonesia pada tahun 2012, demam tifoid atau paratifoid juga menempati urutan ke 3 dari 10 penyakit terbanyak dari pasien rawat inap di rumah sakit tahun 2012 yaitu sebanyak 41.081 kasus dan yang meninggal 274 orang (Kementrian RI, 2012).

Penyakit demam tifoid dipengaruhi oleh tingkat higienis individu, sanitasi lingkungan, dan dapat menular melalui konsumsi makanan atau minuman yang terkontaminasi oleh feses atau urin orang yang terinfeksi (WHO, 2015). Oleh karena itu demam tifoid diharuskan mendapat perhatian yang lebih serius dari berbagai pihak, karena penyakit ini bersifat endemis dan mengancam kesehatan masyarakat (Purba, dkk., 2016).

Di Indonesia penyakit menular masih menjadi masalah kesehatan masyarakat yang menimbulkan kesakitan, kecatatan, dan kematian yang tinggi. Berdasarkan cara penularanya penyakit menular terbagi dalam dua bagian utama, meliputi penyakit menular langsung dari penderita dan penyakit tidak menular langsung, yakni penularan penyakit melalui media seperti, udara (air borne), vektor (vector borne) dan melalui maknan/minuman/benda lainya (vehicle borne). Salah satu penyakit menular tidak langsung melalui vehicle bornr, yaitu demam tifoid ( Noor,

2013).Penelitian ini bertujuan untuk mengetahui karakteristik penderita demam tifoid yang menjalani rawat inap Kabupaten Pekalongan.

\section{METODE}

Penelitian ini bersifat observasional (non eksperimental) menggunakan pendekatan kohort 
retrospektif dengan data penelitian berupa rekam medis pasien demam tifoid pada tahun 2018 di RSUD Kraton Kabupaten Pekalongan kemudian penelitian ini dianalisis secara distribusi frekuensi. Pengambilan sampel dengan tehnik purposive sampling (tidak acak) berdasarkan pertimbangan kriteria insklusi dari penelitian.

Kriteria inklusi meliputi pasien dengan diagnosa demam tifoid maupun demam tifoid beserta penyakit lain, nomor rekam medis, usia pasien serta jenis lamin pasien. Penelitian ini dilakukan di RSUD Kraton Kabupaten Pekalongan pada tanggal 23 Mei sampai 23 juni tahun 2019 di ruang Filling RSUD Kraton Kabupaten Pekalongan

\section{HASIL}

Penelitian ini dilakukan di RSUD Kraton Kabupaten Pekalongan dengan nomor izin penelitian dari BAPPEDA dengan nomor surat: 070/697 dan surat izin penelitian dari RSUD Kraton Kabupaten Pekalongan dengan nomor surat: $\quad 423.4 / 0374 . \quad$ Kemudian mengumpulkan data rekam medik pasien rawat inap yang menderita demam tifoid pada periode tahun 2018 . Sampel yang digunakan yaitu pasien demam tifoid yang mendapatkan antibiotik dan masuk kedalam kriteri inklusi. Jumlah pasien demam tifoid pada tahun 2018 sebanyak 343 pasien kemudian berdasarkan rumus slovin didapatkan hasil 185 sampel.

Tabel 1.Distribusi pasien demam tifoid berdasarkan jenis kelamin di RSUD Kraton Kabupaten Pekalongan

\begin{tabular}{clcc}
\hline No & Jenis Kelamin & Jumlah & Presentase (\%) \\
\hline 1 & Perempuan & 119 & 64,3 \\
2 & Laki - laki & 66 & 35,7 \\
\hline & Jumlah & 185 & 100 \\
\hline
\end{tabular}

Tabel 2. Distribusi pasien demam tifoid berdasarkan usia di RSUD Kraton Kabupaten Pekalongan

\begin{tabular}{lcc}
\hline \multicolumn{1}{c}{ Klasifikasi Usia“ } & Jumlah & Presentase (\%) \\
\hline Balita Usia 0-5 tahun & 15 & 8,1 \\
Kanak-kanak usia 6 - 11 tahun & 13 & 7,0 \\
Remaja awal usia 12 - 16 tahun & 15 & 8,1 \\
Remaja akhir usia 17 - 25 tahun & 43 & 23,2 \\
Dewasa awal 26 - 35 tahun & 18 & 9,7 \\
Dewasa akhir 36 - 45 tahun & 23 & 12,4 \\
Lansia awal 46 - 55 tahun & 22 & 11,9 \\
Lansia akhir 56 - 65 tahun & 19 & 10,3 \\
Manula 66 - ke atas & 17 & 9,2 \\
\hline Jumlah & 185 & 100 \\
\hline
\end{tabular}


Tabel 3. Distribusi pasien demam tifoid berdasarkan diagnosa di RSUD Kraton Kabupaten Pekalongan

\begin{tabular}{lcc}
\hline \multicolumn{1}{c}{ Diagnosa } & Jumlah & Presentase (\%) \\
\hline Demam tifoid & 144 & 77,8 \\
$\begin{array}{l}\text { Demam tifoid dan penyakit } \\
\text { penyerta }\end{array}$ & 41 & 22,2 \\
\hline Total & 185 & 100 \\
\hline
\end{tabular}

\section{PEMBAHASAN}

Tabel 1 dapat diketahui bahwa dalam penelitian ini pasien perempuan lebih banyak yang terdiagnosa demam tifoid di Instalasi Rawat Inap RSUD Kraton Kabupaten Pekalongan tahun 2018 yaitu sebanyak 119 pasien (64,3\%). Jikadibandingkan dengan pasien laki-laki yaitu sebanyak 66 pasien $(35,7)$ lebih sedikit. Pada penelitian yang diteliti oleh Sulistiati pada tahun 2013 didapatkan pasien laki-laki lebih banyak terjadi dibandingkan dengan pasien perempuan.

Penelitian ini sama halnya dengan penelitian Nadyah (2014) menunjukkan bahwa responden terbanyak adalah perempuan sebanyak 37 (74\%) sedangkan laki-laki sebanyak 13 orang $(26 \%)$. Jenis kelamin perempuan jauh lebih beresiko dibandingkan dengan jenis kelamin laki-laki dalam penelitian ini. Sedangkan penelitian yang diteliti oleh Pramitasari (2013) yang menyatakan bahwa laki-laki memiliki risiko menderita demam tifoid dibandingkan dengan perempuan dikarenakan lakilaki lebih banyak beraktivitas di luar rumah sehingga mengkonsumsi makanan siap saji atau makanan warung yang biasanya banyak mengandung penyedap rasa dan kebersihan yang belum terjamin, dibandingkan wanita yang lebih menyukai masakan dari rumah dari pada masakan dari luar rumah sehingga perempuan lebih memperhatikan keberhasilan makanan yang akan dikonsumsi, kebiasaan ini menyebabkan laki-laki lebih rentan terkena penyakit yang diluarkan melalui makanan seperti demam tifoid (Astuti, 2010). Hasil penelitian sesuai dengan laporan Kementrian Republik Indonesia(Kemenkes, 2011) menjelaskan bahwa penyakit demam tifoid ditemukan lebih banyak pada perempuan dari pada pada laki-laki.

Berdasarkan Tabel 2 distribusi tertinggi berdasarkan usia adalah kelompok usia remaja akhir usia 17 25 tahun sebanyak 43 pasien $(23,2 \%)$, 
disusul pada kelompok dewasa akhir usia 36 - 45 tahun sebanyak 23 pasien $(12,4 \%)$, lansia awal usia $55-65$ tahun sebanyak 22 pasien (11,9\%), lansia akhir usia 55 -65 tahun sebanyak 19 pasien $(10,3 \%)$, kemudian disusul dari kelompok manula usia 65 - ke atas sebanyak 17 pasien (9,2\%), untuk kelompok balita usia $0 \quad-5$ tahun dan remaja awal usia 15 - 16 tahun yaitu sebanyak 15 pasien $(8,1 \%)$ kemudian untuk hasil yang paling sedikit pada kanak - kanak usia 5 - 11 tahun $(7,0 \%)$, penelitian ini tidak sama dengan penelitian yang diteliti oleh Sulistiati (2013) untuk kasus demam tifoid paling banyak pada usia 36 - 65 tahun yaitu sebanyak 28 kasus $(45,90 \%)$.

Penelitian ini sejalan dengan penelitian yang diteliti oleh Nadyah (2014) dengan judul hubungan faktorfaktor yang mempengaruhi insidens penyakit demam tifoid, Usia responden dengan umur kurang dari 20 tahun sebnayak 11 orang (22\%) sedangkan responden dengan usia lebih dari 20 tahun adalah 39 (78\%).

Pada Tabel 3 distribusi berdasarkan diagnosa penyakit pada pasien demam tifoid yang didiagnosa dengan penyakit penyerta sebanyak 41 pasien $(22,2 \%)$ sedangkan untuk pasien yang didiagnosa hanya demam tifoid dan tes widal yangpositif sebanyak 144 pasien $(77,8 \%)$.

Penyakit penyerta yang diderita pasien demam tifoid di instalasi rawat inap di RSUD Kraton Kabupaten Pekalongan pada tahun 2018 meliputi diabetes millitus, dispepsia, infeksi saluran pernafasan atas, hipertensi, anemia, epilepsi. Sama halnya dengan penelitian yang dilakukan oleh sulistiati pada tahun 2013 pada distribusi pasien berdasarkan diagnosa dengan penyakit penyerta seperti diabetes militus, hipertensi gastristis, anemia, infeksi saluran pernafasan atas dan demam berdarah.

Data yang diperoleh dapat dilihat kasus demam tifoid yang tes widal positif dan tidak disertai penyakit penyerta sebanyak 144 pasien $(77,8 \%)$ dan demam tifoid serta penyakit penyerta sebanyak 41 pasien $(22,2 \%)$.

\section{SIMPULAN}

Berdasarkan hasil penelitian studi karakteristik pasien demam tifoid rawat inap kabupaten Pekalongan pada periode 2018 yang telah dilakukan dapat disimpulkan bahwa:

1. Karakteristik pasien demam tifoid terbanyak diderita oleh perempuan 
dengan persentase $64,3 \%$ atau sebanyak 119 pasien

2. Karakteristik pasien demam tifoid berdasarkan usia diderita pada Remaja akhir usia 17 - 25 tahun sebanyak 43 pasien dari 185 sampel

3. Karakteritik pasien demam tifoid berdasarkan diagnona, pasien dengan diagnosa demam tifoid saja sebanyak 144 pasien dan pasien demam tifoid dengan penyakit penyerta sebanyak 41 pasien.

\section{UCAPAN TERIMAKASIH}

Penulis mengucapkan terima kasih kepada RSUD Kraton Kota Pekalongan dan Lembaga Penelitian, Pengembangan, dan Inovasi Universitas Muhammadiyah Pekajangan Pekalongan yang telah banyak membantu.

\section{DAFTAR PUSTAKA}

Akdon dan Riduwan, 2010. Rumus dan

Data Dalam Analisis Statistik.

Bandung: Alfabeta.

Astuti. 2010. Faktor yang Mempengaruhi Terhadap Kejadian Demam Tifoid Pada Anak. Skripsi. Surabaya: Universitas Airlangga.
Kementerian Kesehatan Republik Indonesia, 2013. Profil Kesehatan Indonesia. Jakarta: Kementerian Kesehatan Republik Indonesia. Mogasale, V., Ramani, E., lee, S.L., Park, J.Y., Lee, K.S., dan Wierzba, T.F. 2016. Revisiting thyphoid fever surveillance in low and middle income countries: literature review of populationbesad longitudal studies. $B M C$ infection Desease.

Nadyah. 2014. Hubungan Faktor-faktor yang Mempengaruhi Insidens Penyakit Demam Tifoid di Kelurahan Semata Kecamatan Somba Opu Kabupaten Goa 2013. Jurnal Kesehatan.

Noor, Nur Nasry. (2013). Pengantar Epidemiologi Penyakit Menular (Edisi IV). Jakarta: Rineka Cipta.

Pramitasari, O.P. 2013. Fktor Risiko Kejadian Penyakit Demam Tifoid Pada Penderita di Rumah Sakit Umum Daerah Ungaran. Jurnal Kesehatan Masyarakat.

Purba I. E., Wanda, T., Nugrahini, N., Nawawi , S., dan Kandum, M. 2016. Program pengendalian Demam Tifoid di Indonesia: Media Litbangkes, Vol. 26 No.2. 
Sulistiati, 2013. Potensi Interaksi Obat Pada Pasien Demam Tifoid di Instalasi Rawat Inap RSUD "X" tahun 2011. Surakarta.Skripsi. Universitas Muhammadiyan Surakarta.

World Health Organization. 2015. Antibiotic Resistance Threats in the United states. US Departement of Health and Humas Services. USA 